Artigos

\title{
A (des)confiança na polícia \\ Uma comparação entre a relação do Ministério Público e a polícia no Brasil e na França
}

\author{
Distrust in the police \\ A comparison between the relationship between the Public Ministry \\ and the police in Brazil and France
}

Pedro Heitor Barros Geraldo*
Luiza Felix de Souza Barçante**

\begin{abstract}
Resumo: Este trabalho busca analisar a relação entre a polícia e o Ministério Público no Brasil e na França, através da comparação entre duas pesquisas de campo, contrastando seus dados. No caso brasileiro, trata-se de uma pesquisa de campo sobre a organização do trabalho realizado nos gabinetes da Procuradoria de Justiça do Estado do Rio de Janeiro. Compara-se ela com outra pesquisa em que foi feita a observação de audiências criminais em diferentes fóruns do sudeste francês. Assim, procura-se compreender como estas instituições têm sentidos diversos nesses países, explicitando como a transparência e a cooperação na administração da justiça produzem a confiança entre os atores no caso francês ao passo que a opacidade das formas de produção dos pareceres e a disputa institucional pelo controle sobre os fatos caracteriza tal relação no caso brasileiro.
\end{abstract}

Palavras-chave: Ministério Público. Polícia. Administração de conflitos. Estudos comparados.

*Doutor em Ciência Política pela Université Montpellier (França), professor do Departamento de Segurança Pública da Faculdade de Direito e do PPG em Sociologia e Direito da Universidade Federal Fluminense (UFF) em Niterói, RJ, Brasil, além de Pesquisador do Instituto de Estudos Comparados em Administração Institucional de Conflitos (InEAC) e coordenador do curso a distância de Tecnólogo em Segurança Pública e Social e da Especialização em Políticas Públicas e Gestão Governamental na mesma universidade <pedroheitorbg@yahoo.com.br>.

**Doutoranda em Ciências Jurídicas e Sociais do PPG em Sociologia e Direito na Universidade Federal Fluminense (UFF) em Niteroi, RJ, Brasil, tutora no Curso de Tecnólogo em Segurança Pública e Social da mesma universidade e pesquisadora vinculada ao InEAC e ao Núcleo de Pesquisas sobre Práticas e Instituições Jurídicas (Nupij-UFF) e ao Núcleo de Estudos em Conflito e Sociedade (NECSo-UFF) <luiza.barcante@outlook.com>. Uma versão desse artigo foi apresentada no $38^{\circ}$ Encontro anual da Anpocs no GT Administração de conflitos em perspectiva comparada. Agradecemos à revisão crítica e aos comentários de Ana Paula Mendes de Miranda, que permitiram melhorar a primeira versão.

Civitas, Porto Alegre, v. 17, n. 1, p. 159-176, jan.-abr. 2017

Exceto onde especificado diferentemente, a matéria publicada neste periódico

é licenciada sob forma de uma licença

Creative Commons Attribution-NonCommercial-NoDerivatives 4.0 International License 


\begin{abstract}
This paper seeks to analyze the relationship between the police and prosecutors in Brazil and France, through the comparison of two field surveys, contrasting their data. In Brazil, it is a field research on the organization of work in the office at the Prosecutor's Office of the State of Rio de Janeiro. The other research was the observation of criminal hearings in different forums of the French southeast. So we seek to understand how these institutions have different meanings in these countries: transparency and cooperation in the administration of justice produce trust between the actors in the French case whereas the opacity of the forms of production of opinions and institutional dispute for control over the facts characterized this relationship in the Brazilian case.
\end{abstract}

Keywords: Public Attorney. Police. Conflict management. Comparative studies.

\title{
Introdução
}

Este trabalho analisa a relação entre os policiais e os promotores (e procuradores) de justiça no Brasil e na França, através da comparação entre duas experiências de pesquisas. No processo de orientação da dissertação sobre o trabalho de produção dos pareceres na Procuradoria do Ministério Público do Rio de Janeiro (Barçante, 2015) percebeu-se que a relação institucional entre os Procuradores e suas representações sobre a polícia divergiam muito das formas institucionais entre o Ministério Público e a polícia na França (Geraldo, 2011).

Os juristas consideram que o Brasil e a França pertencem à mesma tradição jurídica do Civil law, caracterizado pela valorização da formalização escrita dos procedimentos, intenso grau de codificação, rigor do direito processual de prerrogativa do estado e liberdade restrita de ação e de interpretação aos operadores do direito que trabalham em instituições. Não obstante repartam uma mesma cultura jurídica, esses países possuem diferentes formas de organizar o sistema legal, o estado, as leis, os procedimentos e as instituições.

A pesquisa de campo na Procuradoria de Justiça ocorreu entre 2012 e 2014 (Barçante, 2015). Analisando a formação do parecer criminal, compreende-se de que forma é realizada a qualificação do crime na segunda instância, destacando os constrangimentos que orientam sua formação. Em contraste, compara-se com outra realizada entre 2008 e 2010, em que foi feita a observação de audiências criminais em diferentes fóruns do sudeste francês (Geraldo, 2011). Nas audiências criminais observadas, os representantes do Ministério Público e os policiais estavam em uma relação coordenada. 
A divisão do trabalho entre estas instituições demonstra como a transparência e a cooperação na administração da justiça produzem a confiança entre os atores no caso francês ao passo que a opacidade das formas de produção dos pareceres e a disputa institucional pelo controle sobre os fatos caracteriza tal relação no caso brasileiro.

\section{A comparação entre as organizações}

Os juristas enfatizam sempre as semelhanças entre os "sistemas de direito" (David, 2002) permitindo universalizar as discussões sobre as instituições supostamente semelhantes. Como observamos, as peças processuais produzidas por promotores e procuradores de justiça se designam comumente como Parquet, ou mesmo, como "magistrados de pé" ("les magistrats débouts") em referência a como são designados os representantes do Ministério Público na organização judiciária francesa.

Entretanto, tomar uma instituição pela outra é incorrer no risco da tradução termo a termo que induz a pensar que as instituições desempenhariam o mesmo papel nos respectivos países (Vigour, 2005). A análise é orientada para uma comparação contrastiva (Kant de Lima, 2009) que permitirá compreender os sentidos atribuídos pelos próprios atores no contexto de uma cultura jurídica institucionalizada.

Em razão disto, a reflexão sobre a relação entre o Ministério Público e a Polícia partirá das práticas observadas em campos de pesquisas distintos. $\mathrm{O}$ objetivo é compreender como os representantes do Ministério Público avaliam e qualificam o trabalho realizado pela polícia ao imputarem valor à "palavra da polícia", como os depoimentos prestados em juízo pelos policiais como testemunhas no processo criminal brasileiro; ou as declarações dos policiais nos processos verbais franceses. Esta relação orienta assim regras práticas de produção de decisão. Estas regras se explicitam na forma como o trabalho de elaboração dos pareceres é realizado pelos procuradores no caso brasileiro; e como os representantes do Ministério Público interpretam o trabalho da polícia em audiência no caso francês.

Os processos de produção da decisão se amoldam, assim, a estes constrangimentos institucionais e contextuais que explicitam sempre estas regras práticas. O objetivo é entender por quais regras estes atores se orientam durante o processo de produção da decisão (Emerson, 1983).

Esta perspectiva praxeológica considera que as normas jurídicas não são unicamente interpretadas por um processo de silogismo por uma única pessoa, mas sim são o resultado de práticas sociais compartilhadas a respeito de como estas regras orientam práticas de administração de conflitos. 


\section{As relações de desconfiança entre o Ministério Público e a Polícia no Brasil}

A pesquisa sobre a organização do trabalho realizado dentro dos gabinetes na Procuradoria de Justiça do Estado do Rio de Janeiro analisa o contexto de atuação e desenvolvimento das práticas cotidianas de administração institucional de conflitos (Barçante, 2015). No processo penal, os promotores de justiça atuam até o momento da sentença. Perante o Tribunal de Justiça, os Procuradores de Justiça trabalham nas sessões de julgamento dos processos das Câmaras Criminais, elaboram pareceres e podem interpor recursos aos tribunais superiores. A ênfase está na função de "parecerista" das procuradorias. Nesta função, cabe ao Ministério Público atuar como fiscal da lei, emitindo um parecer sobre o processo, realizando uma análise dos autos e opinando sobre a decisão proferida em primeira instância aos desembargadores que julgam o caso no Tribunal de Justiça.

A partir do recebimento dos autos em seu gabinete, analistas processuais, assessores e procuradores analisam e interpretam o desenrolar do processo, já com decisão de primeira instância nele proferida. Na maioria dos casos, os assessores e analistas processuais são responsáveis pela produção das primeiras decisões informados pelos "modelos de pareceres" salvos nos computadores e os procuradores pela análise e assinatura desses pareceres.

$\mathrm{Na}$ assessoria de um procurador, pode-se observar como o trabalho de produção de pareceres é realizado e compreender como as regras de elaboração dos pareceres são transmitidas e utilizadas pelos diferentes atores, capturando o direito em ato e em contexto enquanto uma orientação prática em meio aos constrangimentos institucionais e das interações (Dupret, 2010).

Esse conhecimento é aprendido pelos assessores através das práticas do dia a dia. Essa lógica, aparentemente individual, segue uma "ética", no sentido atribuído por Kant de Lima (1995). Este tipo de conhecimento se assemelha ao das "praxes policiais, um conhecimento 'prático', isto é, um conhecimento que só se aprende exercendo as funções policiais e agindo de acordo com a ética policial" (Kant De Lima, 1995, p. 74).

Por outro lado, a transmissão do conhecimento não é universalizada. Não existe uma escola de formação que objetive homogeneizar as práticas profissionais (Boigeol, 2010). A forma de aprendizado não é universalizada porque os critérios não são institucionalmente explicitados e colocados para todos. Não existe, por exemplo, uma avaliação formal de desempenho dos analistas/assessores, que se submetem, tão somente, aos critérios de avaliação do procurador com o qual trabalham. 
Para assegurar o cumprimento das funções institucionais, o Ministério Público possui uma série de garantias e princípios previstos na Constituição da República Federativa do Brasil. O princípio da independência funcional garante liberdade de atuação aos promotores e procuradores, impedindo uma subordinação que não seja às normas jurídicas ou à sua própria consciência (Mazzilli, 2010). Na prática, isso possibilita que eles tomem posicionamentos divergentes em sua atuação quanto à avaliação do mesmo fato. Não existe subordinação funcional entre os membros do Ministério Público, apesar de existir uma hierarquia administrativa em relação à chefia única, o Procurador Geral de Justiça.

Quando o processo está na segunda instância já existe uma decisão proferida pelo juiz. Assim, quanto à qualificação dos depoimentos dos policiais pelo Ministério Público, ela pode ser dividida em duas etapas.

A primeira consiste na avaliação realizada pelos promotores da primeira instância sobre os depoimentos dos policiais que efetuaram a prisão do réu e participaram do inquérito, a fim de iniciar ou não o processo judicial, nesta etapa de conversão de fatos em crimes (Paes, 2013). Não se discute esse primeiro filtro realizado pelo Ministério Público sobre a atuação da polícia, pois o Ministério Público em um primeiro momento deu credibilidade à atuação dos policiais, uma vez que denunciou, apresentou alegações finais, razões ou contrarrazões de recursos e requereu a condenação do réu ao juiz, baseado nestes depoimentos.

A segunda etapa consiste da atuação dos procuradores de justiça quando elaboram os pareceres opinando sobre o caso. É neste momento que os mesmos depoimentos apoiados pelo Ministério Público na primeira instância são desqualificados na segunda instância, quando os procuradores de justiça opinam pela absolvição do réu.

Os casos de tráfico de drogas se apresentam particularmente interessantes no estudo praxeológico da noção da (des)confiança dos procuradores no Brasil em relação à polícia, uma vez que são explicitadas nas peças processuais dúvidas quanto ao valor relativo do testemunho do policial. Nesses processos, a prova oral é fundamental e, às vezes, a única prova dos autos. Quanto à autoria, a prova é praticamente baseada no depoimento dos policiais autores da prisão em flagrante do réu, e a materialidade na droga encontrada por esses mesmos policiais. Assim, ao opinar sobre a revisão de uma sentença criminal de tráfico de drogas, o testemunho do policial adquire um valor relativo, ora servindo para sustentar uma condenação, ora para reforçar a dúvida sobre a ocorrência do fato produzindo uma absolvição. 
Apesar da maioria dos processos darem credibilidade aos depoimentos dos policiais, existem regras práticas que possibilitam a relativização de tais depoimentos. A defesa dos réus nesses tipos de processos busca trazer aos autos testemunhas que atestem sobre o "bom comportamento" do réu ("ele é trabalhador", ou "pai de família", ou "frequenta a igreja", como se lê nos processos) e busca desqualificar o depoimento do policial, que na maioria dos casos é a única testemunha, alegando que o mesmo "armou" para seu cliente, ou que seu depoimento deve ser analisado com reservas, em razão do policial ter interesse pessoal no êxito da demanda já que realizou a prisão do réu.

Uma regra prática para a produção dos pareceres orienta que, quando os depoimentos dos policiais são contraditórios, indica-se a absolvição dos réus. Além disto, outra regra prática diz que é irrelevante a condição de policial para dar maior ou menor valor aos depoimentos. Estas regras são desenvolvidas no trabalho prático de realização dos pareceres e não são regras universais, nem consensuais entre os membros do Ministério Público.

Nesse sentido, segue trecho retirado de um parecer:

[...] os policiais são testemunhas como quaisquer outras, só se podendo negar valor aos seus relatos à vista de algum fato concreto e objetivo, devidamente provado nos autos, que ateste estarem eles mentindo, não bastando alegar, de forma inconsistente e vazia, que eles têm interesse pessoal no êxito da demanda, sem apontar o fato que prove a veracidade dessa alegação [...]. Opondo-se a esses fatos, temos apenas a versão sustentada pelo apelante em juízo, sem o apoio de qualquer prova nos autos, dando a entender que teria sofrido uma 'armação' por parte dos policiais autores da prisão. Versões desse tipo, desgastadas pelo excesso de uso, já perderam qualquer poder de convencimento que um dia possam ter tido [...] a palavra de policiais, como a de qualquer outra testemunha, prescinde de outros depoimentos que the emprestem validade. Não se constatou vontade dos agentes em causar algum prejuizo, nada se revelando, pois, contra a idoneidade da prova acusatória, tornando-se inviável o reconhecimento do postulado in dubio pro reo $[\ldots]$.

Assim, o depoimento dos policiais é contraposto com os depoimentos de outras testemunhas, com a quantidade de drogas arrecadada, ou outros materiais apreendidos (como dinheiro, armas, balança de precisão, ou rádio comunicador) e muitas vezes com a ficha de antecedentes criminais do réu, a fim de se prestar credibilidade ao trabalho efetuado pela polícia. A elaboração dos pareceres e a produção da decisão nos casos não são feitas apenas pelos procuradores e não dependem apenas das regras jurídicas para serem formadas, 
uma vez que são produzidas decisões informais (que não estão no processo) na elaboração dos pareceres que interferem em seu conteúdo (no que está de fato escrito no processo).

Este parecer foi sobre um recurso de apelação interposto pelo Ministério Público contra uma sentença que absolveu a ré por entender que "não restou cabalmente provada a finalidade mercantil da droga apreendida" $(65,7 \mathrm{~g}$ de cocaína) uma vez que,

não foi encontrada em sua residência balança de precisão, anotações concernentes ao tráfico ou mesmo dinheiro. Aliás, a ausência de dinheiro no local não se coaduna com o exercício da traficância, mormente quanto os policiais civis relataram que vários veículos pararam no local durante a noite (supostamente para adquirir droga).

A primeira análise realizada pelo assessor manteve a absolvição a partir de uma regra de trabalho que informa ser importante ler a fundamentação do juiz na sentença para captar as razões da decisão pelo fato do juiz participar da audiência e estar em contato com as partes.

Na segunda análise, o procurador de justiça sugeriu a condenação da ré pelo delito de tráfico por conta da quantidade e pela forma de acondicionamento da droga apreendida, bem como pelo fato da ré ter 8 anotações de crimes em sua ficha de antecedentes criminais, o que faz dela uma "bandidinha". Quanto à quantidade da droga, o procurador, após se informar com um colega por telefone, disse que "- Isso é muita droga para alguém cheirar sozinho". No parecer constou que a finalidade de traficância era evidente pela apreensão de 65,7g de cocaína acondicionada em 48 saquinhos plásticos, bem como pela apreensão de

outros bens comuns no âmbito da comercialização de entorpecentes, quais sejam, grampeador, agenda com anotações e embalagens com sacos plásticos (sacolés) ainda sem utilização.

O Tribunal de Justiça manteve a absolvição da acusada por entender que "o quantitativo expressado se impunha para utilização na casa de veraneio".

Noutro processo, o Ministério Público recorreu contra uma sentença que absolveu o réu por tráfico. O promotor de justiça informou que os policiais receberam denúncia anônima sobre uma pessoa com determinadas características comercializando drogas. A polícia encontrou as drogas em um mato próximo ao réu e disseram que o acusado somente admitiu a traficância após a droga ter sido encontrada. O juiz absolveu o réu por entender que 
[...] para um dos policiais o réu, ao ser surpreendido, teria negado estar traficando, admitindo a prática após a droga ser localizada. Para a outra testemunha, o réu ficou silente num primeiro momento e, com a localização da sacola com drogas, teria admitido trabalhar para o tráfico. Ademais chega a soar estranho (dando uma conotação de excesso de justificativa) quando o policial ' $F$ 'dá conta que a quantia em espécie encontrada com o réu era pequena porque ele havia acabado de começar a fazer as vendas. Afinal, que rapidez foi essa entre o início da traficância, a denúncia por populares e a prisão do réu? [...] a versão mais digna de confiança é aquela apresentada, de maneira firme pelo acusado em sua autodefesa; não merecendo credito, por todas as razões aduzidas, os depoimentos dos policiais [...].

O parecer manteve a absolvição. O procurador considerou a primariedade do réu e o fato dele "não ser bandidinho", o fato do mesmo morar perto da boca de fumo, o que possibilita que ele transite pela localidade, de trabalhar e da droga ter sido encontrada no mato e não com ele.

Noutro caso, a defesa recorreu contra uma sentença que condenou o réu pelo delito de tráfico de droga, alegando ser "usuário". Os policiais declararam que estavam em patrulhamento quando abordaram o coletivo da empresa " $X$ ". Após busca pessoal, apreenderam 22,2g de cocaína, distribuídas em 25 cápsulas, além de 3 papelotes contendo 5,4g de maconha. Segundo os policiais, o réu teria admitido que as drogas se destinavam à venda. Entretanto, o réu afirmou em juízo que as drogas eram para uso pessoal, tendo as adquirido na favela porque o preço é inferior ao praticado no município em que morava.

Na sentença, o juiz fundamentou a condenação nos seguintes termos:

[...] A questão nodal diz respeito [...] ao destino do entorpecente, se para uso próprio ou mercancia. Reconheço que muitas vezes a linha divisória entre o uso e o tráfico é muito tênue, na medida em que muitos usuários elou viciados traficam para sustentar o próprio vício. No caso, aqui, ainda que não se queira levar em conta a palavra dos policiais, no sentido de que o réu teria livremente confessado o destino comercial da droga, tenho que uma pessoa normal, em circunstâncias normais, não costuma transportar, para uso próprio, o número de papelotes que o réu trazia consigo [...]. Não acredito, portanto, que a droga era para uso próprio; estou convencido, até pela forma de acondicionamento do entorpecente, que este se destinava ao comércio, no que para tanto o acusado foi buscar o material ilícito em outra cidade para difundi-lo aqui $[\ldots]$. 
O parecer da procuradoria não deu crédito ao testemunho dos policiais considerando plausível a versão do acusado de ser "usuário", pois o mesmo trabalhava como ajudante de pedreiro e por considerar que a quantidade de drogas era compatível com o uso pessoal durante o período de carnaval.

Outro parecer foi sobre um recurso contra uma decisão que rejeitou a denúncia em relação ao crime de associação para o tráfico de drogas por entender que a peça não continha a exposição do fato criminoso, com todas as suas circunstâncias.

Na primeira análise realizada pelo assessor, o parecer manteve a rejeição da denúncia, pois não haveria nos autos indicação dos nomes aos quais o acusado estaria associado, nem informações sobre a forma que ele atuava $o$ grupo, não havendo comprovação de estabilidade e permanência ou de "liame subjetivo" entre o acusado e pessoas envolvidas com o tráfico de drogas naquela região. $\mathrm{O}$ procurador de justiça perguntou se no processo constava um apelido específico do réu: "- Esse processo é sobre o fulaninho de tal?" Como a resposta do assessor foi negativa, o parecer não foi alterado.

As regras jurídicas são, assim, mais um dos constrangimentos dentre as regras práticas de avaliação da prova oral, de análise dos depoimentos e de identificação da contradição neles, da organização dos autos, da avaliação da ficha de antecedentes criminais do réu, do nome do réu, das razões dos recursos e da fundamentação da sentença. São regras práticas vagas, ambíguas e particularizadas em cada gabinete que somente são apreendidas a partir da observação da prática profissional.

\section{A cooperação no centro da relação entre Ministério Público e Polícia na França}

Em contraste, compara-se com outra pesquisa realizada entre 2008 e 2010 em que foi feita a observação de audiências criminais em diferentes fóruns do sudeste francês (Geraldo, 2011). Nas audiências criminais observadas, os representantes do Ministério Público e os policiais mantinham uma relação coordenada. As audiências sempre se iniciam com os juízes perguntando aos réus, se estes reconhecem os fatos declarados no boletim de ocorrência da polícia que se encontra no processo. Se eles os reconhecem, o presidente em seguida passa a palavra ao representante do Ministério Público. Do contrário, o réu expõe sua versão dos fatos (ou seu advogado). Neste momento, observase como a relação é próxima entre a polícia e os representantes do Ministério Público. Em diversas ocasiões, os policiais estavam presentes ou tinham se manifestado por escrito no processo acerca de questionamentos realizados pelo representante do Ministério Público. 
O sistema de justiça criminal francês se divide entre a Polícia Judiciária, que é exercida pela Gendarmeria, a Polícia Nacional, a Polícia de fronteira e a Guarda Municipal sob a direção do Procurador da República. No âmbito judiciário, as jurisdições de proximidade têm competência para julgar as contravenções (até as de quarta classe, que constituem as infrações de trânsito majoritariamente); o Tribunal de Polícia competente para julgar as contravenções de quinta classe (violências que provoquem interrupção de 8 dias de trabalho à vítima); o Tribunal Correcional (composto de três juízes) é competente para julgar os delitos; enquanto a Cour d'Assises (correspondente ao tribunal do júri) seria competente para julgar os crimes (as infrações mais graves como homicídio, roubo com arma, rapto e estupro, por exemplo).

No caso francês, o princípio da indivisibilidade do Parquet faz com que todos os Procuradores da República (Procureurs de la République, que atuam nos Tribunais de Correcionais) e os seus Substitutos (Substituts que atuam nos Tribunais de Polícia) sejam intercambiáveis. Por esta razão, Procuradores e Substitutos estão submetidos ao princípio do engajamento de processamento (le principe de l'engagement de poursuites) em que um ato praticado por um membro engaja os outros que não podem mudar de orientação. Outro princípio importante para compreender a estrutura do Ministério Público francês é a subordinação hierárquica dos Substitutos ao Procurador da República que pode chamar para si um processo em responsabilidade de um Substituto ou atribuílo a outro Substituto. Além disto, os Comissários de Polícia (Comissaires de Police) atuam como Officiers du Ministère Public nas jurisdições de proximidade para o caso se julgamento de contravenções (Rassat, 2007).

Esta organização do Parquet se transformou a partir das reformas judiciárias no início da década de 1980 com o objetivo de permitir uma aproximação dos membros do Parquet e as políticas de segurança pública das cidades. Os Procuradores passaram a integrar "Grupos locais de tratamento da delinquência" nas Casas da Justiça e do Direito que são geridas por um comitê de policiais, eleitos locais e representantes de serviços públicos (transporte, escola e serviços sociais). Estas Casas da Justiça e do Direito são mantidas através de um acordo entre a municipalidade e o judiciário (Wyvekens, 1997). Desta forma, os procuradores têm a responsabilidade de formular políticas locais de administração de conflitos juntamente com policiais e representantes locais. Este papel revela uma forte relação entre as instituições.

A proximidade com que o Parquet trabalha com os policiais não se encerra nesta instituição, mas também no procedimento de comparecimento imediato, no qual o suspeito sob custódia do estado ("en garde à vue") pode ser levado a julgamento caso o Parquet reúna provas suficientes para tanto e a 
pena não ultrapasse dois anos de prisão, nem tenha um procedimento especial previsto por outra lei, ou seja, um delito político e de repercussão. As pesquisas sobre este procedimento indicam como os diferentes membros do Ministério Público colaboram entre si para a administração dos conflitos através de uma "cultura de grupo" (Christin, 2008), mas também para a administração dos processos numa "lógica de urgência" (Mouhanna; Bastard, 2010). No entanto, outro aspecto da relação entre a Polícia e os Substitutos é a cooperação, a proximidade e a relação de confiança (Christin, 2008; Mouhanna, 2004).

Nas audiências das jurisdições de proximidade, onde atuam os Officiers $d u$ Ministère Public, a relação com a polícia é direta. O próprio Officier é um comissário de polícia. Esta atribuição institucional faz com que este comissário de polícia se identifique como "representante da sociedade", como afirmou um deles em audiência a um jurisdicionado.

Durante as audiências, os processos de tomadas de decisão se tornam explícitos e, desta forma, observáveis e descritíveis (Lynch, 1998). A descrição das audiências nos permite compreender como a tomada de decisão é orientada por regras práticas explicitadas durante a própria audiência e pelas quais os diferentes atores presentes compartilham o sentido das falas e das interações (Geraldo, 2013). Ao mesmo tempo, os jurisdicionados podem aprender e negociar através da linguagem dos juristas (Pollner, 1979).

Desta forma, as regras práticas para tomadas de decisão também são orientadas a partir da relação entre polícia e o Parquet. Ela é explicitada nas falas dos Officiers e dos juízes que não hesitam em manifestar a relação de confiança institucional existente entre Ministério Público e Polícia neste contexto.

As audiências de Police nas jurisdições de proximidade têm a presença do juiz, do secretário da audiência (Greffier), do Officier do Ministério Público e do Huissier (quem faz as intimações e chama os casos nestas audiências), além dos advogados e dos réus, vítimas e testemunhas sempre presentes nestas audiências. O procedimento de julgamento começa quando o juiz entra na sala. O Huissier chama os réus, que podem se apresentar com ou sem advogado. As vítimas também são chamadas para constituir a Partie civile, isto é, para poder formular o pedido de danos materiais e morais quando são pertinentes. $\mathrm{O}$ procedimento começa com a leitura do PV (o processo verbal), onde constam os relatos dos policiais e também a assinatura do réu. Em seguida, é dada a palavra ao Officier que faz suas requisições. A palavra então é franqueada ao réu (ou seu advogado). A vítima também se manifesta antes do juiz tomar sua decisão. As decisões são tomadas logo em seguida; no final da audiência - ou são proferidas numa data posterior que é indicada neste momento da audiência. 
A maior parte das decisões são tomadas logo em seguida às manifestações das partes do processo.

$\mathrm{Na}$ presença de todos, a audiência transcorre em silêncio, quando se pode ouvir o que o juiz e os demais dizem. Esta dinâmica permite aos demais interessados aprender como se comportar e o que dizer durante a audiência (Geraldo, 2013). Há um forte componente moral nas falas do juiz e do Officier que repreendem aos réus por seu comportamento relatado no processo verbal, ou mesmo pela forma como se apresentam e falam durante a audiência. "Faire la morale" é a expressão que os franceses utilizam para as repreensões de cunho moral ao comportamento dos outros. Os próprios juízes reconhecem que fazem isto frequentemente durante as audiências. Os juízes têm um poder de polícia sobre a audiência. Assim, as repreensões aos advogados e aos jurisdicionados são frequentes quando os celulares tocam, o volume das conversas na sala aumenta, ou quando as pessoas permanecem sentadas quando deveriam estar de pé diante do juiz.

A compreensão de que a palavra do policial tem um valor importante para orientar a tomada de decisão é institucionalmente compartilhada pelo juiz. Numa audiência do Tribunal de Police, um grupo de assistentes dos Guardas Municipais estava aguardando uniformizados o início da audiência. Antes de chamar os processos, o juiz começa uma cerimônia de juramento destes assistentes. A Procureure pediu que eles fossem leais ao juiz e que escrevessem apenas a verdade nos Processos Verbais. O juiz ditou o juramento. Os assistentes de pé diante do juiz levantaram a mão direita e disseram: - "Eu juro".

Noutra audiência, um caso em que um rapaz embriagado e nervoso cuspiu no policial. Após ressaltar este fato na leitura do processo verbal, o juiz deu a palavra ao Ministério Público. Nas suas requisições, o Procureur constatou que o réu não teria mais direito ao sursis caso fosse condenado à prisão, que pareceu desproporcional para o caso. Então, disse: “-Eu não sei o que requerer de proibi-lo de beber, de proibi-lo de ficar nervoso... Eu requeiro uma pena de $€ 200$ contra ele." Numa audiência da jurisdição de proximidade, o juiz leu o processo verbal num caso de excesso de velocidade em que o réu foi parado pela polícia. O juiz disse: “-Eu leio, por que eu estou enjoado pela sua resposta ao policial”. E explicou que o réu disse que estava dirigindo rápido para poder comprar um tênis. O Officier, em seguida, complementou: “- Eu também estou chocado." E requereu $€ 600$ de multa e 3 meses de suspensão da carteira de motorista.

Em ambos os casos, o desrespeito à institucionalidade representada pelos policiais foi ressaltada nas decisões. Sendo motivos para comentários tanto 
dos membros do Ministério Público, quanto do juiz. Esta institucionalidade não se manifesta apenas quando ela é desrespeitada, mas também colocada em questão. $\mathrm{Na}$ audiência da jurisdição de proximidade, o juiz leu o processo verbal de um senhor que estacionou o carro em local inapropriado e foi multado pelo policial. O réu contesta perguntando: "-Onde eu poderia estacionar?" $\mathrm{O}$ Officier retruca: “- Sem uma prova em contrário..." O réu reage novamente: “- Qual prova eu poderia trazer? Eu deveria ter tirado uma foto? Isto supõe que eu tenha uma." O Officier responde novamente: "- Você poderia ter ido na sua casa para pegá-la." O réu inconformado diz: “- Desculpe-me, senhor, mas eu moro longe. É a palavra contra a palavra [referindo-se ao relatado no processo verbal]. Qual o espaço que me resta para fazer a prova em contrário?" O Officier diz em tom mais severo: "- Eu tenho a palavra de um Oficial juramentado" referindo-se ao policial que realizou o processo verbal.

Noutra audiência, o processo verbal em questão tratava de um motorista que dirigia sem o cinto de segurança. O Officier, sempre de pé para fazer suas requisições, pediu "dois minutos de pedagogia" para explicar a questão ao réu. Este defendeu-se dizendo que o processo verbal não era válido, pois o carro estava em movimento e se afastou da polícia. Ele alegou que não cometeu o crime de fuga. O Officier retomou a palavra e explicou que não era por esta razão que o réu estava ali. E continuou afirmando que o processo verbal era válido por que "o policial é juramentado".

Outro caso em que o réu foi acusado de ultrapassar o sinal vermelho, o Officier pediu $€ 250$ de multa e 15 dias de suspensão da carteira de motorista. Em sua defesa, o réu disse que o sinal estava verde. O juiz falou: "-Você disse que você passou no sinal verde? - Não, eu passei no amarelo." Respondeu o réu. "- Sim, está escrito por suas mãos" disse o juiz. O réu completa: “- Não, foi a polícia que escreveu. - Mas você assinou” retruca o juiz. “- Não" responde o réu. O juiz relendo o processo verbal constata que ele realmente não assinou: “- Desculpe-me, você não assinou." Mesmo assim, o tom da conversa sugeriu que o réu estava colocando a versão da polícia em questão. A única prova era o relato do processo verbal que não foi contestado pelo juiz publicamente que reduziu a multa em sua condenação a $€ 150 \mathrm{e}$ confirmou os 15 dias de suspensão da carteira de motorista. Noutra audiência, o réu contestava o fato de que ele não estava dirigindo o veículo quando foi multado. E que a foto na multa não permitia identificar quem estava dirigindo. O Officier explicou que o radar que realizou a foto era particular, pois havia um na entrada do túnel cuja velocidade máxima permitida era de $90 \mathrm{~km} / \mathrm{h}$, enquanto na saída era de $80 \mathrm{~km} / \mathrm{h}$. E que o réu era o proprietário do veículo e, 
portanto, como não havia a transferência da responsabilidade a outra pessoa, ele responderia pela multa. O Officier afirmou irritado com as contestações do réu: “- O juiz tem outros problemas para resolver [ele usou a expressão "avoir d'autres chats à foueter"]. Você é o proprietário do veículo. Eu não tenho mais questões, senhor presidente." Ao final, requereu $€ 450$ de multa. $\mathrm{O}$ juiz condenou o réu a $€ 250$ de multa se referindo às explicações "úteis do comissário". E ainda ressaltou o fato de que era lamentável que as pessoas contestassem o trabalho da polícia.

Os relatos presentes nos processos verbais nunca são colocados em questão, mesmo quando são exclusivamente preenchidos pela polícia. Tanto os Procuradores, quanto os Officiers sublinham o fato de que a polícia é juramentada e que não é possível colocar em questão a palavra da polícia a todo tempo. Durante a audiência, isto se torna uma regra importante explicitada nas interações descritas acima. Aliás, questionar a polícia torna-se um elemento que pesa negativamente contra os réus. O trabalho da polícia é enaltecido a partir de suas relações institucionais como o juramento e sua responsabilidade com o Parquet.

Outra regra percebida negativamente pelo Officiers é a ausência dos réus no julgamento das contravenções (majoritariamente infrações de trânsito) pela jurisdição de proximidade. Neste procedimento, quando alguém é autuado, a multa pode ser paga, ou recorrida ao judiciário. Este recurso é encaminhado ao Ministério Público para que responda. Em muitos casos, os Officiers revisam o trabalho dos policiais, chamando-os a dar explicações suplementares ao processo verbal. A ausência daqueles que recorrem na audiência é vista como um sobretrabalho inútil. Como um Officier disse numa audiência: "-Eles nos fazem trabalhar por nada." Estes procedimentos são julgados ao final da audiência, quando a sala já está vazia. Em diferentes fóruns, a regra se apresentava da mesma forma, como disse um juiz: “- Se eles não estão presentes, a gente não tá nem aí [ele usou uma expressão francesa em tom coloquial “on s'en fiche”]!” Estar presente para apresentar as razões pela qual recorreu e discorda da multa é uma atitude percebida como indispensável para estes atores. Os valores das multas são comumente majorados nestas ocasiões e todos confirmados pelos juízes que compartilham a mesma impressão dos representantes do Ministério Público.

\section{Os significados da (des)confiança institucional}

Estas regras práticas, que orientam a tomada de decisão nestes contextos, explicitam formas de relação institucionais entre a Polícia e o Ministério Público. 
No caso brasileiro, percebe-se na avaliação das práticas para a produção dos pareceres como o trabalho das outras instituições estão em contato e são representadas por estes procuradores. Atuando como revisor na segunda instância, o Ministério Público avalia o trabalho realizado por outras instituições, como a polícia (apreciando a qualidade dos depoimentos dos policiais que são testemunhas nos processos criminais); o poder judiciário (corroborando, ou não, um entendimento consolidado numa sentença); mas também da própria instituição (acolhendo, ou não, o recurso interposto por um promotor de justiça da primeira instância).

No Brasil, Paes (2013, p. 337) afirma existir "sistemas de segurança e de justiça", uma vez que a polícia é considerada uma instituição separada do sistema judiciário, contrariamente ao sistema de justiça francês onde o "aparelho de justiça é integrado, porque os inquéritos fazem parte do processo sem nenhum problema de legitimidade". A pesquisa no Ministério Público do Rio de Janeiro explicita tal campo de disputa, mas não apenas entre policiais e promotores, uma vez que todas as instituições que operam na administração de conflitos concorrem na administração simbólica do direito. Elas demonstram a hierarquia entre estas instituições.

Esta hierarquia não é funcional, mas em relação ao conteúdo do trabalho, uma vez que os Procuradores não apenas avaliam a atuação dos policiais, mas também modificam o significado do que é apresentado pelos policiais. Porém, esta desconfiança institucionalizada não se apresenta na forma de identificação da responsabilidade dos diferentes atores. Nenhuma responsabilidade dos policiais é apurada em caso de uma interpretação diferente dos fatos, assim como o próprio entendimento dos Procuradores não é colocado em questão nestes casos.

Por outro lado, a confiança entre os representantes do Parquet e os policiais franceses é explicitada nos diferentes tipos de audiências criminais através do reconhecimento de um valor da palavra dos policiais. O juramento dos policiais não possui um sentido apenas formal, mas é usado como argumento institucional para construir esta confiança. Esta confiança entre Procuradores e Substitutos é salientada por outras pesquisas que demonstram a cumplicidade e a cooperação entre os Parquetiers e os policiais, que possuem uma relação menos hierarquizada do que se supõe, em razão da proximidade em que trabalham nos procedimentos de comparecimento imediato (Mouhanna; Bastard, 2010). Nas audiências, observou-se que quando as declarações da polícia eram questionadas quanto a sua veracidade, o juiz e o representante do Ministério Público explicavam que os policiais eram juramentados e que, portanto, não poderiam mentir. Assim, as contestações fundadas neste 
argumento eram interpretadas de uma forma negativa. Como os julgamentos eram realizados no final da audiência, pode-se constatar como isto pesava contra os réus nas condenações.

Mesmo as políticas de segurança pública indicam como estas diferentes instituições se articulam em ambos os países. A noção de proximidade surge com a articulação das instituições no sistema criminal francês (Wyvekens, 1997). As diferentes políticas de segurança pública fizeram dos membros do Parquet atores indispensáveis na articulação das instituições do sistema de justiça criminal. Pesquisas mais recentes demonstram como a própria identidade profissional dos Procuradores e Substitutos incorporou esta dinâmica cooperativa com a polícia. Milburn (2010) afirma que os Procuradores se encontram hoje no centro das políticas de segurança pública, uma vez que atuam com autonomia para gerir as questões locais sem prescindir das diretivas estabelecidas pela hierarquia institucional.

No Brasil, ao caracterizar a relação enquanto uma desconfiança institucional pretende-se explicitar esta relação hierárquica no caso brasileiro entre as instituições no campo da segurança pública (Kant de Lima, 1995; Mendes de Miranda; Beraldo de Oliveira; Paes, 2007; Misse, 2011). As políticas de segurança pública não conseguem produzir estas relações de proximidade e cooperação entre Ministério Público e policiais (Paes, 2010).

Como conclusão, a divisão do trabalho entre estas instituições demonstra como a transparência e a cooperação na administração da justiça produzem a confiança entre os atores no caso francês ao passo que a opacidade das formas de produção dos pareceres e a disputa institucional pelo controle sobre os fatos caracteriza tal relação no caso brasileiro.

\section{Referências}

BARÇANTE, Luiza F. de S. O "meu", o "seu" e o nosso: a gestão particularizada do trabalho realizado no Ministério Público do Estado do Rio de Janeiro. Dissertação de Mestrado. Niterói: Universidade Federal Fluminense, 2015.

BOIGEOL, Anne. A formação dos magistrados: do aprendizado na prática à escola profissional. Revista Ética e Filosofia Política, v. 2, n. 12, p. 61-97, 2010.

CHRISTIN, Angèle. Comparutions immédiates: enquête sur une pratique judiciaire. Paris: Editions La Découverte, 2008.

DAVID, René. Os grandes sistemas do direito contemporâneo. São Paulo: Martins Fontes, 2002.

DUPRET, Baudouin. A intenção em ação: uma abordagem pragmática da qualificação penal num contexto egípcio. Revista Ética e Filosofia Política, v. 2, n. 12, p. 109-140, 2010. 
EMERSON, Robert M. Holistic effects in social control decision-making. Law \& Society Review, v. 17, n. 3, p. 425-456, 1983.

GERALDO, Pedro H. B. La proximité au palais: une analyse de la socialisation des juges de proximité. Sarrebruck: Éditions Universitaires Européennes, 2011.

GERALDO, Pedro H. B. A audiência judicial em ação: uma etnografia das interações entre juristas e jurisdicionados na França. Revista Direito GV, v. 9, n. 2, p. 635-658, 2013.

KANT DE LIMA, Roberto. Por uma Antropologia do Direito, no Brasil. In: Roberto Kant de Lima. Ensaios de Antropologia e de Direito. Rio de Janeiro: Lumen Juris, 2009. p. 1-38.

KANT DE LIMA, Roberto. A polícia na cidade do Rio de Janeiro. Rio de Janeiro: Forense, 1995.

LYNCH, Michael. Preliminary notes on judges' work: the judge as a constituent of courtroom "hearings". In: Max Travers; John F. Manzo (eds.). Law in action: ethnomethodological and conversation analytic approaches to law. Farnham: Ashgate Publishing, 1998. p. 99-130.

MAZZILLI, Hugo Nigro. A atuação do Ministério Público na segunda instância. Revista Plural, v. 14, n. 41-42, 2010 <www.mazzilli.com.br> (26 ago. 2014).

MENDES DE MIRANDA, Ana Paula; BERALDO DE OLIVEIRA, Marcella; FERREIRA PAES, Vívian. Antropologia e Políticas Públicas: Notas sobre a avaliação do trabalho policial. Cuadernos de Antropología Social, v. 25, p. 51-70, 2007.

MILBURN, P. Les procureurs de la République: passeurs de justice ou gestionnaires des “politiques pénales”? Droit et Société, v. 74, n. 1, p. 73-90, 2010.

MISSE, Michel. O papel do inquérito policial no processo de incriminação no Brasil: algumas reflexões a partir de uma pesquisa. Sociedade e Estado, v. 26, n. 1, p. 15-27, $2011<10.1590 /$ S0102-69922011000100002>.

MOUHANNA, Christian. Les relations police-parquet en France: un partenariat mis en cause? Droit et Société, v. 58, n. 3, p. 505-520, 2004.

MOUHANNA, Christian; BASTARD, Benoit. Procureurs et substituts: l'évolution du système de production des décisions pénales. Droit et Société, v. 74, n. 1, p. 35-53, 2010.

PAES, Vívian G. F. Crimes, procedimentos e números: estudo sociológico sobre gestão dos crimes na França e no Brasil. Rio de Janeiro: Garamond, 2013.

PAES, Vívian G. F. Sobre limites e expectativas da sociedade civil com relação à criação de uma política municipal de segurança. In: Roberto Kant de Lima; Lucía Eilbaum; Lenin Pires (orgs.). Conflitos, direitos e moralidades em perspectiva comparada. Niterói: Garamond, 2010. v. 2. p. 87-109.

POLLNER, Melvin. Explicative transactions: making and managing meaning in traffic court. In: George Psathas (ed.). Everyday language: studies in Ethnomethodology. New York: Irvington, 1979. p. 229-255.

RASSAT, Michèle-Laure. La justice en France. 8. ed. Paris: PUF, 2007. 
VIGOUR, Cécile. La comparaison dans les sciences sociales: pratiques et méthodes. Paris: La Découverte, 2005.

WYVEKENS, Anne. L'insertion locale de la justice pénale aux origines de la justice de proximité. Paris: l'Harmattan, 1997.

Recebido em: 23 jun. 2016

Aprovado em: 16 fev. 2017

Autor correspondente:

Pedro Heitor Barros Geraldo

Rua Álvares Borgerth, 15, apto. 505 - Botafogo

22270-080 Rio de Janeiro, RJ, Brasil 